\title{
School counselors' beliefs regarding collaboration with parents of students with special educational needs in Flanders: Parents as partners or opposites?
}

Bodvin, K., Verschueren, K., Struyf, E. (2018b). School counselors' beliefs regarding collaboration with parents of students with special educational needs in Flanders: Parents as partners or opposites? British Educational Research Journal, 44(3), 419-439. doi:10.1002/berj.3333

\begin{abstract}
:
Literature shows that good collaboration between the school and parents of students with special educational needs (SEN) is not always present. However, school counselors must collaborate with SEN students' parents to organise guidance trajectories for their child. This study examines school counselors' experiences when collaborating with parents of SEN students and the factors they perceive as contributing to good or difficult collaboration. Four focus groups in mainstream education $(N=50)$ and one focus group in special education $(N=14)$ were conducted in Flanders. A thematic analysis indicated that school counselors generally find it difficult to collaborate with parents of SEN students and that an expert attitude can emerge. The role of these parents is described as limited, which is even preferred by some school counselors. A deficit view is recognised and the reasons for poor collaboration are mainly situated on the parents' side, such as parents that need more processing time to accept the SEN of their child and that show distrust towards the school. School counselors spontaneously referred to parents' low socioeconomic and ethnic minority status as complicating factors for collaboration. They seem to feel incompetent to overcome these collaboration difficulties. Various recommendations for schools are formulated.
\end{abstract}

Keywords: special educational needs, school counselor, collaboration, parents. 


\section{Introduction}

This study focusses on the interaction between the home and school environment in organising guidance for students with special educational needs (SEN) in compulsory education. Here, SEN students are defined as those students with difficulties in participating in mainstream education and who receive additional student guidance within and/or outside the mainstream school. Key school professionals in the collaboration with parents of SEN students are school counselors. This study therefore explores how school counselors in mainstream and special compulsory education in Flanders experience collaborating with parents during student guidance trajectories.

In the introduction, collaboration in student guidance trajectories in Flanders and other countries is described. Concerning the latter, student guidance in the UK and the Netherlands is outlined particularly, to show concrete similarities and differences between Flanders and other countries.

\subsection{Student Guidance in Flanders and Internationally}

Student guidance in mainstream education is defined here as guidance for the benefit of students' academic and socioemotional development that is provided in addition to the standard support of learning in school. Student guidance can refer to minimal adaptions to the classroom or school environment. If necessary, gradually these adaptions become more intensive and more specialized and diverse professionals become involved in the student guidance trajectory, such as extramural support services. Students can also change schools within mainstream education or, in Flanders and in other countries with a separate special education track, move into special education schools ${ }^{1}$ (Bodvin, Verschueren, \& Struyf, under review). Both school and parents must agree upon each decision regarding the appropriate student guidance intervention (Pameijer, 2006).

In Flanders, key school-related professionals regarding student guidance are the school-internal counselor and the professional from the Pupil Guidance Centre $\left(P G C^{2}\right)$. School-internal counselors are responsible for student guidance in four domains: academic development, psychosocial development,

\footnotetext{
${ }^{1}$ In Flanders, education is compulsory and free of charge from the age of 6 through 18. Children from 2.5 to 6 can attend nursery education. Primary education is provided for children aged 6 to 12 years old and comprises 6 consecutive years of study. Secondary education is provided for adolescents aged 12 to 18 years old. Students are awarded a diploma of secondary education after successfully completing six or seven years of schooling. Alongside mainstream education, a separate track of 'special education' exists for pupils with a disability. Special education is provided from nursery through secondary education in mainstream or separate special education schools where adjusted final terms need to be achieved.

${ }^{2}$ PGC are government-financed centers that join school psychological services and preventive youth healthcare (Struyf, Verschueren, Vervoort, \& Nijs, 2015).
} 
school career and preventive healthcare. A PGC professional supports school personnel with more complex needs of students, can assess students' needs and can act as a gateway for student guidance measures outside mainstream schools (Struyf et al., 2015). In this study, both the school-internal counselor and the PGC professional are considered "school counselors".

\subsubsection{Policy and Training: Needs-Based Assessment Model}

Flemish legislation states that school-internal counselors are the first contact person for parents and that they organise conferences with parents, while PGC professionals are expected to not only collaborate with parents but also to support collaboration between school personnel and parents. Also, a needsbased assessment model (NBA) for addressing children's SEN has been implemented in Flemish educational policy (M-decree). This model describes a systematic decision-making process for making recommendations for students' guidance trajectories in which collaboration between school and parents is essential (Pameijer, 2006). Its implementation is encouraged by the European Agency for Special Needs and Inclusive Education (Pameijer \& Pijl, 2006).

A literature review by Pameijer (2006) and experiences from assessment experts ${ }^{3}$ regarding quality indicators of student guidance processes, have led to seven coherent principles for the NBA model, one of which concerns school-parent collaboration: (1) It is goal-directed, aimed at meaningful and useful decisions and recommendations; (2) A transactional frame of reference on development is used, in which the focus is on the mutual influence between the student, school professionals, and family members (Bronfenbrenner, 1977); (3) Students' educational needs are key, (4) as well as teachers' and parents' needs in supporting the student's development; (5) Protective as well as risk factors related to the child, school and parents are considered; (6) Collaboration between the teacher, child and parents is imperative; (7) NBA follows a systematic and transparent process in several stages. At each stage and for every decision, agreement and thus collaboration is necessary (Pameijer, 2006). In NBA, each partner is equal, has specific knowledge and makes a valuable contribution. It emphasises that parents have got the final say in decisions about student guidance trajectories (Pameijer, 2006).

In Flanders, the only formal training requirement for school-internal counselors is to have a teaching degree. Most school-internal counselors have previous experience in teaching. Also they may combine their function with teaching, especially in secondary education (Struyf et al., 2015). Only a minority of the school-internal counselors have a master degree in psychology or education (Struyf, Verschueren,

\footnotetext{
${ }^{3}$ As formulated in a meeting of assessment experts organised by the European Agency for Development in Special Needs Education (Brussels, November 2005).
} 
Verachtert, \& Adriaensens, 2012). PGC professionals work in multidisciplinary teams consisting of professionals with a bachelor in social work and nursing, and a master in psychology, education, and medical science (Verschueren \& Jonniaux, 2015). In general, only in teacher training and the master in psychology and education, the NBA model is part of the curriculum. In addition, most school-internal counselors and PGC professionals take training courses relevant to student guidance including NBA training.

\subsubsection{Collaboration and Special Educational Needs}

Schools are ideally positioned for helping students with additional needs and can serve as a gateway for appropriate assistance (Pameijer, 2006; Tucker, 2009). However, and in contrast with the NBA model, internationally good collaboration between schools and SEN students' parents is not always present (European Commission, 2012; Gamble \& Lambros, 2014; Lendrum, Barlow, \& Humphrey, 2015; PereraDiltz \& Mason, 2012; Siddiqua \& Janus, 2017; Tétreault et al., 2014) and is particularly difficult in the case of ethnic minority and low socioeconomic status (SES) families (Hess, Molina, \& Kozleski, 2006). Previous research points to the critique of school professionals who state that parents should be more interested and involved in the educational career of their child (Hornby \& Lafaele, 2011). To our knowledge, little is known about parents' role in decision-making concerning the student guidance measures. According to survey research in Flanders, this collaboration with parents seems to be limited to requesting information from and giving information to parents (Struyf et al., 2012). In addition, previous research revealed frustration among these SEN students' parents about the decision process, and discrepant views between schools and parents concerning the students' needs (Hess et al., 2006; Siddiqua \& Janus, 2017; Tétreault et al., 2014). The latter was especially prominent when school professionals perceived the student or his parents as deficient (Lamb, 2009).

Indeed, previous research points to a deficit view among school professionals towards SEN students' parents in general (Trent, Artiles, \& Englert, 1998) and particularly towards ethnic minority and low SES SEN students' parents (Hess et al., 2006), here all considered as 'disadvantaged parents's . Deficit theory describes school professionals' interpretations of the differences between the dominant habits, values and norms in education and the non-dominant counterparts in disadvantaged families as deficits inherent in disadvantaged families (Clycq, Nouwen, \& Vandenbroucke, 2014). School professionals with a deficit view can reason that an individual's success is dependent on personal characteristics and earnings. In that way, they minimises their own responsibility (Clycq et al., 2014; Dierckx, Coene,

\footnotetext{
${ }^{5}$ Although grouped together here, students' SEN can be independent of families' ethnicity and SES.
} 
Raeymaeckers, \& Burg, 2015; Nicaise, 2008).

However, this deficit view can lead to discouraging and exclusionary behaviour towards parents. Disadvantaged parents' interventions and suggestions for addressing their child's SEN are not always respected, valued and attended to (Siddiqua \& Janus, 2017). These parents can feel talked down to and blamed for their child's problems (Broomhead, 2013; Tucker, 2009). Schools oftentimes leave no room for compromise and expect conformity with their expectations (Tucker, 2009). As a consequence, parents of SEN students in general, and ethnic minority and low SES parents of SEN students in particular, often experience a lack of control over their child's school career, can hold negative feelings about the school and avoid contact with school professionals (Lamb, 2009; Tucker, 2009). At the same time, school counselors have reported their frustration with these parents because they do not follow their recommendations and sometimes label them as "annoying" (Van Hove et al., 2009). In previous research in Flanders with ethnic minority and low SES parents of SEN students, these parents did not feel they had been treated differently compared to parents of majority groups and were satisfied with the school-internal and school-external student guidance. However, indirectly, a power imbalance was noticed; these parents felt inferior and sometimes were afraid of (school) professionals (Bodvin, Verschueren, De Haene, \& Struyf, 2017).

In other words, school professionals still seem to define how and when parents are involved. This power imbalance is particularly prominent in the interaction with ethnic minority and low SES parents of SEN students (Salas, 2004). Nevertheless, school professionals who do involve these parents, look at them more positively and are less likely to stereotype them (Epstein \& Sanders, 2000).

\subsubsection{Student Guidance in other European Countries}

Although policies, processes and procedures regarding student guidance trajectories can differ across countries and various professionals can be involved (e.g., school psychologists ${ }^{6}$, school-internal and school-external student counselors), in most countries student guidance is a school policy issue and some type of school counselor is active in schools ${ }^{7}$. School counselors preventively and proactively coordinate and implement individual or group guidance measures within schools in collaboration with teachers, the principal, and parents. Whenever necessary, they also refer to extramural support services or special education schools (Perera-Diltz \& Mason, 2012; Struyf et al., 2015). The training of school counselors varies from having no specific training, to having a bachelor in social work, nursing, a

\footnotetext{
${ }^{6}$ School psychologists' training is comparable in different countries (Struyf et al., 2015).

${ }^{7}$ Various names are used for school counselors: school-based counselor, school psychologist, educational psychologist, school social worker, school nurse, school-based mental health provider (Struyf et al., 2015).
} 
bachelor/master in teacher training (with or without additional training in special needs education), education, or school psychology (B. Harris, 2013; Struyf et al., 2015).

Comparable to Flanders and other countries (B. Harris, 2013; Struyf et al., 2015), in the UK and the Netherlands school-based counselling is well established but not mandatory (B. Harris, 2013), school counselors take on various tasks in student guidance (Baginsky, 2004; Pameijer, 2016), legislation stimulates school-parent collaboration (Cooper, 2013; Pameijer, 2016; Williams, Williams, \& Ullman, 2002), and the training of school counselors varies from bachelors in teaching to masters in special needs education or psychology (Baginsky, 2004; B. Harris, 2013). Comparable to Flanders, in the Netherlands, the NBA model has also been implemented in educational settings (Pameijer, 2006).

Concerning school-parent collaboration, a survey $(N=278)$ and case study $(N=38)$ research in primary and secondary schools in the UK (Kane et al., 2003) showed that parents of SEN students were not always involved in decisions concerning student guidance trajectories. When they were involved, they mainly could give comments on the school's propositions. Also, school professionals stated that involving parents can cause a strain in the school, as collaborating with parents is time-consuming (Kane et al., 2003). Survey research in primary schools in the Netherlands with 44 teachers, 47 school counselors and 32 parents of SEN students, asking to affirm or disconfirm the correct implementation of NBA principles, found that these were implemented well, with the exception of the collaboration with the student. Eighty-eight to ninety-four percent of the participants affirmed a school-parent partnership in student guidance processes (Pameijer, 2016).

\section{Current Study}

Good collaboration between schools and parents is important for all students, and particularly for SEN students. However, there are indications that collaboration between the school and parents of SEN students, and of ethnic minority and low SES SEN students specifically, is difficult to achieve. Previous research mainly investigated the perspectives of SEN students' parents (Bodvin et al., 2017; Salas, 2004), teachers or principals (Clycq et al., 2014; Crozier \& Davies, 2007) on this form of collaboration, whereas in this study focusses on the school counselors' perspectives. The following research questions are addressed qualitatively:

- How do school-internal counselors and PGC professionals experience collaborating with parents of SEN students? How do they view the parents' role in student guidance processes?

- What factors contribute to good or difficult collaboration? To what extent do school counselors hold a 
deficit view in school-parent collaboration?

\section{Method}

School counselors' perspectives are examined exploratory using a qualitative method, namely focus group discussions. Focus groups are suitable for exploring experiences and opinions (Krueger, 1997).

\subsection{Participants}

School-internal counselors and PGC professionals were interviewed in five focus groups: one in mainstream nursery education (school counselors: $N=4$; PGC professionals: $N=5$ ), one in mainstream primary education (school counselors: $N=3$; PGC professionals: $N=10$ ), one in mainstream general secondary education (school counselors: $N=8$; PGC professionals: $N=8$ ), one in mainstream vocational secondary education (school counselors: $N=6$; PGC professionals: $N=6$ ), and one in primary and secondary special education (school counselors: $N=6$; PGC professionals: $N=8$ ).

For each focus group 18 schools and PGC's were selected using aselect stratified sampling according to educational level, educational network and school location. Schools and PGC's were not related to each other so that we could receive varied information and to minimise social desirability. The selected schools and PGC's were sent an email followed by a telephone call, until enough participants were found. A surplus of participants was recruited, because previous experience warned us that participants regularly cancelled at short notice.

In each focus group, two members of the research team acted as moderators. Researcher 1 guided the focus group and asked questions, whereas researcher 2 observed, took notes and assisted with practical issues. Researcher 1 had previous experience in focus group interviews, while researcher 2 did not.

\subsection{Procedure}

Participants were asked to prepare two cases of student guidance trajectories, namely one perceived successful and one perceived faulty case. In the mainstream education focus groups, the student guidance trajectories could involve school-internal and school-external student guidance with or without a possible referral to a special education school. In the special education focus group, the student guidance trajectory concerned a change of school from a mainstream to a special education school.

All focus group discussions followed the same semi-structured interview guide, in which general 
questions were followed by key questions (Yin, 2010). This interview guide probed personal experiences and perceptions regarding issues concerning the student guidance trajectory as a whole: the decision process, involved individuals and their roles, encountered difficulties, and the perceived quality of the student guidance processes. When answering the questions all participants elaborated spontaneously on the collaboration with SEN students' parents. Questions specifically about the collaboration with parents were: "Who played what role in decision-making about initiating a student guidance trajectory?", "Who did what?", "Was the contribution of different individuals involved equal?", "Considering the vision of different individuals involved is not easy. How did you cope with that?". Probing and clarifying questions were asked to reach an in-depth understanding. The focus groups were recorded with a camera and lasted three hours. The spoken language was Flemish.

\subsection{Analyses}

The audio recordings were transcribed by a master student. Researcher 1 analysed the ad verbatim transcripts thematically using Nvivo (Braun \& Clarke, 2006), which is suitable for focus group data (Howitt, 2010). Themes and subthemes were coded inductively and deductively by researcher 1 respectively by using in vivo coding and sensitising concepts (Campbell, Quincy, Osserman, \& Pedersen, 2013; Yin, 2010). The coding was reviewed by and discussed with the research project coordinator. In addition, the latter researcher and multiple experienced professionals in student guidance trajectories reviewed the analysis. Through this triangulation in reviewers, the themes and subthemes were revised and, if necessary, adjusted in order to minimise potential unconscious bias of researcher 1 , increasing the dependability and validity of the results (Cohen, Manion, \& Morrison, 2013).

\section{Results}

The following themes emerged in the focus groups: the role of the school and the parents of SEN students, the difficulty of collaborating with these parents, the reasons for this difficult collaboration, and collaboration with ethnic minority and low SES parents of SEN students. These themes were equally prominent in all focus groups, with the exception of the theme concerning ethnic minority and low SES parents of SEN students. With regard to the latter theme, relatively more references were made in the vocational secondary and special education focus groups, presumably because ethnic minority and low SES students are overrepresented in these tracks in Flanders (Dierckx et al., 2015). Unless stated otherwise, no remarkable differences were found between the perspectives of school-internal 
counselors and PGC professionals.

\subsection{Role of School and Parents}

Participants across focus groups considered themselves as educational professionals to be the most important person in coordinating and managing student guidance trajectories. In all focus groups, participants described the role of the parents as rather passive. Indeed, in the described cases, only a minority of parents actively and fully participated in the student guidance processes. Participating school counselors did not labelled the passive role of parents as good or bad. Participants said they should not forget to contact parents and ask their opinion, that they should inform parents of their advice, and give them feedback more regularly. They sometimes needed to convince parents of the necessity of the student guidance trajectory. The school team often discussed in advance what advice to give to parents. Mostly, the school counselors only informed parents about this advice or gave them a choice between limited predefined options. This was done with nothing but good intentions.

School-internal counselor6: At the end of the school year, we illustrated the options to the parents: staying within the current mainstream school, with restricted guidance, or changing to a special education school. The parents did not react and, therefore, we initiated the limited guidance measures for their child. (FG Primary Education).

In eleven cases spread out over all focus groups, parents played a more prominent role as the guidance measures became more intense. These parents made suggestions, initiated certain student guidance measures or assertively contradicted the school's advice. Some participants seemed to admire these parents for their perseverance (FG Nursery Education, FG Special Education). These parental actions seemed unexpected to the participating school counselors.

School-internal counselor2: You see that parents sometimes really do stick up for their children. (FG Special Education)

Although this active parental involvement was labelled as adaptive by some participants, it was labelled annoying by other participants. Indeed, in the rare cases where participants described a more prominent parental role, parents' suggestions, initiatives and assertiveness were experienced as difficult by the participants. School counselors did not always agree with the initiation of (certain) student 
guidance measures by parents. Often, the school counselors perceived a lack of efficiency and coordination of the various student guidance measures that had been started (FG Nursery Education, FG Primary Education, FG General Secondary Education). School counselors could even find it disturbing when parents had read about their child's problems and asked questions about the school's measures (FG Nursery Education, FG Primary Education).

PGC professional10: I think that there is a trend where many parents ask us if their child can go to a special education school. They think this is evident and become angry when we ask some critical questions about their child's school career. (FG Primary Education)

School-internal counselor1: The mother seemed intelligent. She looked up all the advice we gave, so it seemed as if a professional was present during those conferences and that sometimes caused difficulties. She asked us about all the possible actions we could do, from A to Z. (FG Nursery Education)

In line with this minimal collaboration with parents, the added value of parents' involvement in a student guidance processes was described explicitly in only one focus group. School counselors in the mainstream nursery education focus group believed that parents may give the school and PGC new insights because they know their child best. Therefore, they said it is important to engage parents in a timely manner when investigating students' problems and when looking for appropriate student guidance.

School-internal counselor3: Parents sometimes know their child better than the school. Plus, children can behave differently at home than in school. Sometimes I am happy that we respected parents' resistance towards certain of our student guidance advices. (FG Nursery Education)

Contrary to the above mentioned limited parental involvement, participants in all focus groups acknowledged that the final say about the student guidance trajectory is made by the parents. Participants stated that parents must agree to allow changes to the student guidance trajectory and are therefore key figures.

\subsection{Collaborating with Parents is Difficult}


In all focus groups, the participants talked about collaboration with parents in general and more specifically about how this collaboration should be. When asked about the collaboration in concrete student cases, the collaboration with parents was generally described as difficult. According to most participants, difficulties arose because parents held a different point of view regarding their child's problem than school counselors. In that case, school counselors stated that parents' involvement in the student guidance process acted as a barrier and some described parents as annoying. Also, in a number of cases spread out over the five focus groups $(N=15)$, the parents rejected the student guidance advice from the school. At least one participant in each focus group experienced the parents' final say as obstructive. In all focus groups, some participants were convinced that the parents' decisions were detrimental to the child.

School-internal counselor4: The collaboration was difficult because parents don't understand the problem and don't ask for help. If parents say "no", it is difficult to make progress, which is a pity. (FG General Secondary Education)

PGC professional3: We have sometimes tried to change the parents' view and they stopped communicating with the school. (FG Nursery Education)

PGC professional3: If parents themselves do not want to recognise the problem, it is annoying. (FG General Secondary Education)

PGC professional2: It is regrettable that I could not help the child without the permission of the parents. (FG Vocational Secondary Education).

PGC professional9: The child's development is limited, because the mother does not agree with our advice. (FG Primary Education).

In a few cases spread out over all focus groups the collaboration with parents was described as positive $(N=7)$. In these cases, the school counselors coordinated the student guidance process and parents had an equal input. Parents and school counselors shared similar ideas or the school counselor respected the parents' perspective that contrasted with his or her vision. Two cases made clear that a good collaboration with parents did not necessarily lead to compliance of the parents with school's 
advice (FG Nursery Education, FG Vocational Secondary Education).

PGC professional4: The father convinced me. I asked him, "Sir, you say your child is averagely gifted. How do you see that?" He explained that his child could do certain things, which convinced me that that the student did not have a mental disorder. (FG Nursery Education)

PGC professional3: In my case, the school had a very good relationship with those parents, the school involved them and told them "You are the home experts and we are the school experts". In cases of good collaboration, parents are more open to the school's advice. (FG Vocational Secondary Education)

PGC professional5: It is important that the relationship with the parents remains good even if they do not comply with the school's advice. If the relationship with the parents stays good and you do not push them and show them respect, they shall give you a second chance if the student's problems remain. (FG Nursery Education)

\subsection{Reasons for Difficulties in Collaboration with Parents}

Across focus groups, most participants considered parental variables as reasons for difficult collaboration. A first set of reasons concerned family and parental characteristics such as unstable home situations, problematic parenting and disagreements between parents in divorce (FG Nursery Education, FG General Secondary Education, FG Vocational Secondary Education).

PGC professional7: In my case, the two parents agreed with each other, but sometimes they absolutely do not. However, in making decisions about student guidance trajectories it is necessary for them to agree. (FG Vocational Secondary Education)

A second set of reasons for difficult collaboration concerned factors in the collaboration process. However, the participants that referred to these process factors were in minority compared to participants who situated reasons for difficult collaborations with the parents. Only one participant in the nursery education focus group and one in the vocational secondary education focus group explicitly blamed the process. Across focus groups, mainly PGC professionals, stated (mostly indirectly) that parents' resistance could arise from shortcomings in the collaboration process, such as involving parents 
too little or too late, and giving them insufficient processing time to cope with their child's problems and accept a potential referral.

PGC professional6: If parents resist, then I wonder "Where in the process did it go wrong?" Then I think we may have to look at ourselves to find the reason for the parents' resistance. (FG Vocational Secondary Education)

PGC professional 6: As long as parents are not ready to start a guidance trajectory, you cannot do much (FG Primary Education)

One reason mentioned for difficult collaboration was that parents need more processing time to accept the SEN of their child. Participants in each focus group experienced difficulties in balancing the time given to parents for processing and that given to tackling problems in a timely manner. Providing sufficient processing time for parents is not always desirable from the school's perspective (FG Primary Education, FG General Secondary Education, FG Vocational Secondary Education, FG Special Education). Teachers often want immediate solutions to problems. Also, by allowing parents more processing time, the child's difficulties could increase. According to participants in the vocational secondary education focus group, in urgent cases or in potentially dangerous situations, one must act quickly and ignore the fact that parents need processing time.

PGC professional1: It is not reasonable to always follow the pace of parents. If you think the situation is dangerous, then you take responsibility and take action. (FG Vocational Secondary Education)

Nevertheless, there were a few cases where school counselor's patience had facilitated the parents' acceptance of the school advice ( $N=4$; FG Nursery Education, FG Primary Education, FG Vocational Secondary Education, FG Special Education). A PGC professional in the nursery education focus group explained that giving parents enough processing time is a necessary step in decision-making.

PGC professional4: I think that giving parents' processing time helps us to guide them towards certain decisions. (FG Nursery Education) 
Third, in all focus groups, participants agreed that parents and the school should have a good relationship with one another to establish a successful guidance trajectory for the student. An important prerequisite for a good relationship is that parents trust the school and the PGC, according to the participants. Nevertheless, participants agreed that developing a trustful relationship takes time and effort which is not always available, and even then, success is not guaranteed (FG Nursery Education, FG Primary Education, FG General Secondary Education, FG Vocational Secondary Education).

In the vocational secondary education focus group, a PGC professional contradicted another participants who said they put a lot of effort into convincing parents to comply with their student guidance advice. The PGC professional noticed that "convincing" parents never works, and instead endorsed the importance of collaborating with them to formulate joint decisions.

PGC professional5: I have never succeeded in convincing parents of a certain student guidance measure. Through collaboration, I have reached shared agreement, but I have never been able to convince parents of a certain step. (FG Vocational Secondary Education)

One PGC professional in the nursery education focus group was convinced that it was detrimental for the collaborative relationship with parents to initiate conferences based on what was "wrong" with students or about their weaknesses, rather than discussing their capabilities or talents. When parents ask for advice themselves it facilitates collaboration, according to this participant.

PGC professional4: Very often, advice is only formulated for students' weaknesses and schools want to sell this advice to parents. It never works. The parents must ask for advice themselves before they comply with our advice. So, it is so important to have a good relationship right from the start because otherwise you shall meet resistance. (FG Nursery Education)

\subsection{Collaborating with Ethnic Minority and Low SES Parents}

In the previous paragraphs, we described that participants labelled the collaboration with parents of SEN students in general as difficult. Additionally, participants mentioned specific difficulties related to collaborating with ethnic minority and, to a lesser extent, low SES parents of SEN students, although this was no specific focus in the interview guide. First, we look at the difficulties related to communication and, second, to the other difficulties. 


\subsubsection{Difficulties in Communication}

Participants in all focus groups described difficult communication with the non-vernacular speaking parents of SEN students. Participants indicated that a different parental mother tongue can be a barrier for school counselors for engaging with these parents and relaying important information. Daily informal communication with non-vernacular speaking parents is either limited or absent. One participant explained that conferences with these parents are often postponed until the problems have become so big that something must be done immediately. Also, one can wait until a more formal meeting in the presence of an interpreter (FG Nursery Education).

School-internal counselor2: The parents' non-vernacular mother tongue is already a barrier when discussing student guidance trajectories. Teachers do not approach these parents as spontaneously as native parents. During parent-teacher conferences, communication is difficult and teachers do not really want to give detailed messages on their own, so the meeting is postponed to a later consultation where the teacher and school-internal counselor or PGC professional or interpreter are present. One could do more at short notice if there was no language barrier. (FG Nursery Education)

Participants elaborated on the communication difficulties they experienced due to different cultural backgrounds and other ways of communicating with parents of SEN students (FG Nursery Education, FG General Secondary Education, FG Vocational Secondary Education, FG Special Education). Some participants encountered a gap between their (western) culture and the culture of certain ethnic minority families (FG General Secondary Education, FG Vocational Secondary Education, FG Special Education). A PGC professional in the vocational secondary education focus group said that the communication in some cultures is more direct than that that of western cultures. According to the participants in that focus group, expectations about communication are influenced by one's culture, which complicates communication between those with different cultural backgrounds. A PGC professional seemed to think that this is counterproductive for decision-making concerning student guidance trajectories (FG Vocational Secondary Education).

PGC professional3: We have got a teacher of Moroccan origin at school and I am stunned at how differently she interacts with the immigrant youths. When we communicate, we each give our opinions and we ask each other what we think. In contrast, the Moroccan teacher says to her 
students "What did I say to you?!" and the youths reply, "Yes, Madam, you said X." "Well, did you do that?" "No." "Are we going to do that now?" "Yes." Their way of communicating is so different. (FG Vocational Secondary Education)

The statements of participants in all focus groups show that they did not know how to deal with the communication difficulties arising from diverse cultural backgrounds. For example, one PGC professional mentioned that, despite her investment in culturally sensitive communication, she was frustrated because she failed to get her message across adequately to those parents (FG Vocational Secondary Education).

PGC professional5: With some families I get the impression that I am speaking in Chinese despite good intentions. (FG Vocational Secondary Education)

Interpreters and intercultural mediators were used to promote conferences with non-vernacular speaking parents (FG Nursery Education, FG Primary Education, FG Vocational Secondary Education, FG Special Education). A participant, however, also described an example of how parents felt offended when such translators were present, which was recognised by other participants (FG Vocational Secondary Education). It was clear that participating school counselors across focus groups had good intentions and wanted to show initiative when facilitating collaboration with non-native parents. However, it seemed as if they did not always have the necessary information to choose the appropriate initiative or did not always check with parents if the chosen initiatives were fine with them.

PGC professional5: In the first meeting with the parents and a facilitator you notice straight away if it is a good match, as they immediately begin communicating in their mother tongue, or if not, they say "How dare you? We are not retarded and we speak Dutch and we can communicate." (FG Vocational Secondary Education)

Concerning SES, participants in the primary education focus group described that higher educated parents were disproportionally more actively involved in student guidance decisions. According to some participants in the mainstream primary and the two secondary education focus groups, the perceived quality of communication with ethnic minority parents was also influenced by parents' educational level. When highly educated, communication was experienced as being relatively easier. 


\subsubsection{Other Difficulties}

In addition to the difficulties in communication, school counselors in all focus groups experienced cultural differences regarding their vision on education and student guidance. Some parents showed different academic expectations for their children than school counselors. A participant described a case in which the parents' goals contrasted with the goals of the Flemish educational system (FG Nursery Education).

School-internal counselor2: Those parents thought nursery school is the same as day care. (FG Nursery Education)

Second, school counselors said some ethnic minority parents demonstrate a different vision regarding student guidance, prefer solving problems within the family without external professional help, and can find it shameful when families cannot help their own children by themselves (FG Vocational Secondary Education, FG Special Education). The broader family can also put pressure on the parents not to initiate (external) student guidance. A participant in the special education focus group described an experience where an ethnic minority parent agreed to initiate and contact extramural student guidance to satisfy the school and avoid further questioning about this, but failed to do so for this reason.

PGC professional5: We have noticed in certain ethnic minority families a prominent attitude of "solve your problems within your own family". To talk about their problems in school with anyone else is difficult for certain parents. (FG Vocational Secondary Education)

Third, participants experienced that ethnic minority and low SES parent groups have got less accurate information about student guidance options (FG Primary Education, FG General Secondary Education, FG Vocational Secondary Education, FG Special Education). For example, one participant in the special education focus group stated that ethnic minority parents know little about special education schools and associate this track with all sorts of handicaps and severe deficits. As a result, these parents are more resistant to a transition to these schools.

Fourth, a PGC professional described how ethnic minority and low SES parents did not trust professionals (anymore) and were afraid that school counselors would call the police (FG Vocational Secondary Education). Again, this points to an incorrect perception of the goal and process of student 
guidance.

Lastly, only one PGC professional explicitly stated that the prejudices of school counselors could play a role in difficult student guidance processes for ethnic minority and low SES students (FG Special Education). As an example, another PGC professional in the same focus group was convinced that ethnic minority parents are less involved in their child's school career.

PGC professional1: Ethnic minorities are not involved in homework and other aspects of school but think their children should do well in school. (FG Special Education)

\section{Discussion}

This study explored the experiences of Flemish school-internal counselors and PGC professionals when collaborating with parents of SEN students and examined the factors they perceived as facilitating or impeding this collaboration. In this paragraph, we discuss the role of different persons involved and the reasons for difficult collaborations with parents of SEN students in general and with ethnic minority and low SES parents of SEN students specifically, as well as the manifestations of the deficit theory and NBA model.

\subsection{The Role of Different Individuals Involved and the Reasons for Difficult Collaboration}

Most school-internal counselors and PGC professionals in our focus groups considered themselves to be the most important person involved in student guidance decisions and described the role of parents as passive. Although in previous studies school professionals criticized the passive role of parents (Hornby \& Lafaele, 2011), participating school counselors did not explicitly labelled the passive role of parents as good or bad. School counselors' actions were generally done with nothing but good intentions. However, their statements revealed that some school counselors did not give parents the opportunity to actively participate in decision-making. Indeed, most of the time, school counselors only informed parents or gave them a choice between predefined options. In the few cases of active parental participation, parents were admired by the school counselors. Active parental involvement seemed to be unexpected to participants. However, some participants found it annoying when parents asserted themselves and contradicted school advice or initiated student guidance measures. Although the literature states that professionals must be aware of the complexity and depth of parental knowledge about their children (Fisher \& Goodley, 2007), parents' expertise and competency was rarely appreciated. Participating 
school counselors were convinced that their advice was best for the student and that parents' decisions that contradicted their advice were detrimental to the child's development. Throughout these statements of participants an expert attitude emerges.

These results not only confirm previous research findings about the limited and even difficult collaboration between schools and parents of SEN students (Gamble \& Lambros, 2014), but they also suggest that some school counselors prefer limited parental involvement. It seems that participants expected and sometimes even wished parents to passively await and confirm their professional advice without question. Some school counselors seemed uneasy when parents' views or wishes contrasted with their own views or advice, when parents need processing time, and when parents initiated student guidance measures on their own.

Most participating school counselors experienced collaboration with SEN students' parents as difficult and tended to situate the reasons for the difficulties within the parents. Few participants, mainly PGC professionals, saw a less than optimal collaboration process as a reason for these difficulties. Possibly PGC professionals are more inclined to look at process factors, because legislation prescribes their role in supporting collaboration between school personnel and parents. Amongst other things, participants commented on the difficulty of providing parents with enough processing time while handling problems in a timely manner, which endorses the importance of involving parents from the start.

Several contradictions are found in the results regarding the roles of different individuals involved and the reasons for difficult collaborations. First, the passive role and limited involvement of parents and the lack of appreciation for active parental involvement contrasts with the importance of parents' view on their child and the final say of parents in decision-making. Second, some participants said parents needed to be "convinced" of certain student guidance advice, whereas others endorsed the added value gained from parents' perceptions and recognised them having a final say and the importance of good collaborative relationships. Endorsing the latter, one participant noticed that convincing parents never works and that collaborating with them was preferable. Third, a minority of participants saw suboptimal process factors as possible reasons for difficult collaboration, whereas a deficit view, in which the difficulties are seen as deficits inherent to non-dominant families, is also recognised in the participants' elaborations. For example, different participants described the difficulty of providing enough processing time for parents, whereas other participants mentioned that providing enough processing time for parents is essential for collaborative decision-making. These contradictions seem to be indicative for a low quality of collaboration.

The results of the current study are comparable to findings in the UK: Although legislation stimulates 
school-parent collaborations, true school-parent partnerships were limited and school professionals found it difficult to realise this partnership (Kane et al., 2003). On the contrary, in a quantitative study in the Netherlands, the majority of the individuals involved indicated that school-parent collaboration was present (Pameijer, 2016). However, one can reason that the latter judgement can contrast with how independent researchers evaluate school-parent collaboration using focus groups results, as in the current study.

\subsection{Collaboration with Ethnic Minority and Low SES Parents of SEN Students}

Participants found collaborating with ethnic minority and low SES parents of SEN students particularly difficult. Specifically, our results indicate that the non-vernacular mother tongue of parents not only makes communication with them more difficult, but also delays conferences and makes communication more superficial. According to the school counselors in this study, this is because school professionals experience a communication barrier for engaging with non-vernacular speaking parents. In addition, different cultural backgrounds, different ways of communicating, and contrasting views on education and student guidance might complicate collaboration. Participants seemed unsure of how to overcome these difficulties and sometimes chose initiatives that were counterproductive to collaboration.

Concerning SES, school counselors experience was that a high educational level of parents facilitates communication. Also, school counselors indicated that ethnic minority and low SES parents are less informed about student guidance trajectories and that prejudices among school counselors towards these parents still exist. According to participants, these parents might also distrust school counselors, whereas participants labelled trust as an important prerequisite for collaboration.

These results indicate that previous literature describing the perceptions of ethnic minority and low SES parents including a perceived lack of control over the school career of their child, the feeling of being inferior and not listened to by the school (Bodvin et al., 2017; Tucker, 2009), can be explained by the selfperceived expert status of school counselors that undervalues and discourages parental involvement in decision-making. One could argue that the expert attitude of participating school counselors and their preference for limited parental involvement, is a way of dealing with their perceived incompetence in collaborating with ethnic minority and low SES parents. Indeed, previous research found that schools and parents collaborate less during student guidance processes as parents' educational level decreases (Bodvin et al., under review).

\subsection{Deficit Theory}


Evidence of deficit thinking, or thinking about non-dominant norms, values and behaviours as deficits within non-dominant groups (Clycq et al., 2014), was present in the statements made by participants. A clear indication of deficit thinking was demonstrated in the prejudices regarding ethnic minority parents as being less involved in the academic careers of their children. This prejudice impedes the school counselor from approaching these parent groups and so they cannot disconfirm this prejudice.

Indirect indications of deficit thinking were shown in the prevailing expert attitude of most school counselors, and their biased opinions that parents' decisions that contrasts with theirs would be detrimental for the child. Also, most school counselors blamed parents for collaboration difficulties and took limited responsibility for these difficulties. A minority of participants argued that the reason for difficult collaboration with parents could be situated in the actions of school counselors.

\section{Conclusion}

To conclude, although there are difficulties when collaborating with ethnic minority and low SES parents of SEN students, our results indicate that collaborating with parents of SEN students in general seems to be difficult for school counselors. This is unfortunate given the positive impact of school-parent collaboration for the students, parents and the school (A. Harris \& Goodall, 2008; Lendrum et al., 2015). Despite clear guidelines for effective collaboration according to the NBA model, it seems that school counselors generally show difficulties in implementing these guidelines in concrete student guidance processes. Next, we formulate some recommendations for stimulating school-parent collaboration, and we conclude with the strengths and limitations of this study.

\section{Recommendations}

Since schools are ideally positioned to help SEN students (Farmer, Burns, Phillips, Angold, \& Costello, 2003) and paying more attention to collaboration with parents can positively influence the school career of all SEN students, we formulate some recommendations for schools and school counselors in particular, which are based on previous research findings and good practices concerning school-parent collaboration in other countries. The ultimate goal is that school counselors pay attention to forming good collaborations with the parents of SEN students, develop a trusting relationship with parents, and

involve parents trough two-way communication in decision-making regarding their child's guidance trajectory from the start (Nesse, 2012). This can be pursued in several ways. 
First, in general, school professionals should make it clear that the school is hospitable to everyone. Parents can be made to feel more welcome using minimal interventions and initiatives that erode the possible communication barriers between parents and the school (Williams et al., 2002). Also, differentiation can be made in types of conferences. Not only formal structured contacts (Lendrum et al., 2015) but also informal contacts (Williams et al., 2002) are opportunities for collaboration, increasing the accessibility of conferences concerning guidance trajectories (Cooper, 2013). Moreover, communication cannot not be restricted to negative messages and academic progress. Also, positive aspects, psychosocial functioning, possible SENs of the students, and information about what the school and parents can do to support students' needs should be the topic in conferences (Lendrum et al., 2015). In addition, having one contact person for parents can facilitate communication about their child's guidance trajectory (Lendrum et al., 2015). When this contact person invests a sufficient amount of time in building a trusting relationship, potential distrust can diminish.

Second, irrespective of the reasons for difficult collaboration, ideally, schools and PGCs take the initiative to improve these collaborations, since they have got the power and resources to do so (Tétreault et al., 2014). It is helpful if school counselors recognise the added value parents can bring to the process and regard strengths and protective factors of the student and in the different contexts surrounding a student (Bronfenbrenner, 1977; Pameijer, 2006), by using a more holistic approach such as evidenced in Denmark and Sweden (EASNIE, 2010).

Third, something to pursue is that school counselors, PGC professionals and parents are correctly informed about each other's roles. Parents need to be informed about student guidance within and outside the school and how school guidance measures may support the child's development. Also they should be assisted by school counselors in identifying the information most relevant for their child (European Commission, 2012). This may help them to view such guidance as helpful for their child instead of problematic.

Fourth, to achieve this, ideally, school counselors' training consistently includes training in the skills and processes of communicating in collaboration with parents (Davis \& Day, 2010). In that way, school counselors can become confident in working with all parents. More specifically, it is important that school counselors show the necessary (intercultural) communication skills (B. Harris, 2013). Sufficient attention needs to be devoted to conversational techniques and to collaborating with people with nondominant values, norms, behaviours, and cultural backgrounds in teacher training and other professionalisation for school personnel. In that way, school counselors can become confident in working with all parents. In addition, school counselors' training should oppose the deficit view towards low SES 
and ethnic minority parents by endorsing the added value of disadvantaged group characteristics and by utilizing different capacities in education (González, Moll, \& Amanti, 2006). More generally, as this study suggests that key principles of the NBA model are not yet fully implemented in Flemish student guidance, more extensive and formal training of school counselors in implementing these principles may help to improve school guidance practice.

Lastly, a school policy on collaborating with parents of SEN students would be helpful so that school counselors receive clear guidelines, as is outlined in a whole school strategy in the UK (Lendrum et al., 2015). Decision-making concerning a guidance trajectory should be formulated as a shared responsibility of the school, parents, and student, as in the UK (Kane et al., 2003). The task descriptions for school counselors could include structured consultation time and the ability to differentiate between and work with all parents (Lendrum et al., 2015).

\section{Strengths and Limitations}

A strength of this study is that school counselors were interviewed in focus groups, where they could react to each other's statements when they recognised or did not recognise specific situations. Also, participants considered actual student cases which made it possible to gather authentic information. In that way, researchers could evaluate actual school-parent collaboration. One limitation of this study is that it only focuses on school counselors' perspectives regarding parents of SEN students, so we cannot compare these with their perspectives on parents of non-SEN students, nor with the parents' or students' perspectives. As involving SEN students' perspective is also key to the quality of the student guidance process (Pameijer, 2006), it is of paramount importance that future research includes this perspective as well. 
Baginsky, W. (2004). School counselling in England, Wales and Northern Ireland: a review. London: National Society for the Prevention of Cruelty to Children.

Bodvin, K., Verschueren, K., De Haene, L., \& Struyf, E. (2017). Social inequality in education and the use of extramural support services: access and parental experiences in disadvantaged families. [journal article]. European Journal of Psychology of Education, 33(2), 215-233. doi: 10.1007/s10212-017-0335-z

Bodvin, K., Verschueren, K., \& Struyf, E. (under review). Different pathways to student guidance in mainstream education. International Journal of School and Educational Psychology.

Braun, V., \& Clarke, V. (2006). Using thematic analysis in psychology. Qualitative research in psychology, 3(2), 77-101. doi: http://dx.doi.org/10.1191/1478088706qp063oa

Bronfenbrenner, U. (1977). Toward an experimental ecology of human development. American psychologist, 32(7), 513. doi: http://dx.doi.org/10.1037/0003$\underline{066 X .32 .7 .513}$

Broomhead, K. (2013). Blame, guilt and the need for 'labels'; insights from parents of children with special educational needs and educational practitioners. British Journal of Special Education, 40(1), 14-21. doi: 10.1111/1467-8578.12012

Campbell, J. L., Quincy, C., Osserman, J., \& Pedersen, O. K. (2013). Coding in-depth semistructured interviews: Problems of unitization and intercoder reliability and agreement. Sociological Methods \& Research, 42(3), 294-320. doi: $10.1177 / 0049124113500475$

Clycq, N., Nouwen, W., \& Vandenbroucke, A. (2014). Meritocracy, deficit thinking and the invisibility of the system: Discourses on educational success and failure. British Educational Research Journal, 40(5), 796-819. doi: 10.1002/berj.3109

Cohen, L., Manion, L., \& Morrison, K. (2013). Research methods in education: Routledge.

Cooper, M. (2013). School-based counselling in UK secondary schools: A review and critical evaluation.

Crozier, G., \& Davies, J. (2007). Hard to reach parents or hard to reach schools? A discussion of home-school relations, with particular reference to Bangladeshi and Pakistani parents. British Educational Research Journal, 33(3), 295-313. doi: https://doi.org/10.1080/01411920701243578

Davis, H., \& Day, C. (2010). Working in partnership: the family partnership model. London: Pearson Education.

Dierckx, D., Coene, J., Raeymaeckers, P., \& Burg, M. v. d. (2015). Armoede en sociale uitsluiting. Jaarboek 2015. ACCO: Leuven/Den Haag.

EASNIE. (2010). Early Childhood Intervention - Progress and Developments, 2005- 2010. European Agency for Special Needs and Inclusive Education.

Epstein, J., \& Sanders, M. (2000). Connecting home, school, and community Handbook of the sociology of education (pp. 285-306): Springer.

European Commission. (2012). Support for children with special educational needs (SEN). European Commission.

Farmer, E. M., Burns, B. J., Phillips, S. D., Angold, A., \& Costello, E. J. (2003). Pathways into and through mental health services for children and adolescents. Psychiatric services, 54(1), 60-66. doi: http://dx.doi.org/10.1176/appi.ps.54.1.60 
Fisher, P., \& Goodley, D. (2007). The linear medical model of disability: Mothers of disabled babies resist with counter - narratives. Sociology of health \& illness, 29(1), 66-81. doi: http://dx.doi.org/10.1111/j.1467-9566.2007.00518.x

Gamble, B. E., \& Lambros, K. M. (2014). Provider Perspectives on School-Based Mental Health for Urban Minority Youth: Access and Services. Journal of Urban Learning, Teaching, and Research, 10, 25-38.

González, N., Moll, L. C., \& Amanti, C. (2006). Funds of knowledge: Theorizing practices in households, communities, and classrooms: Routledge.

Harris, A., \& Goodall, J. (2008). Do parents know they matter? Engaging all parents in learning. Educational Research, 50(3), 277-289. doi: http://dx.doi.org/10.1080/00131880802309424

Harris, B. (2013). School-based counselling internationally: a scoping review.

Hess, R. S., Molina, A. M., \& Kozleski, E. B. (2006). Until somebody hears me: Parent voice and advocacy in special educational decision making. British Journal of Special Education, 33(3), 148-157. doi: http://dx.doi.org/ 10.1111/j.14678578.2006.00430.x

Hornby, G., \& Lafaele, R. (2011). Barriers to parental involvement in education: An explanatory model. Educational Review, 63(1), 37-52. doi: 10.1080/00131911.2010.488049

Kane, J., Riddell, S., Banks, P., Baynes, A., Dyson, A., Millward, A., \& Wilson, A. (2003). Special educational needs and individualised education programmes: issues of parent and pupil participation. Scottish Educational Review, 35(1), 38-47.

Krueger, R. A. (1997). Analyzing and reporting focus group results (Vol. 6): Sage publications.

Lamb, B. (2009). Lamb Inquiry: special educational needs and parental confidence: report to the Secretary of State on the Lamb Inquiry review of SEN and disability information. UK Digital Education Repository Archive.

Lendrum, A., Barlow, A., \& Humphrey, N. (2015). Developing positive school-home relationships through structured conversations with parents of learners with special educational needs and disabilities (SEND). Journal of Research in Special Educational Needs, 15(2), 87-96. doi: 10.1111/1471-3802.12023

Nesse. (2012). Education and disability/special needs: policies and practices in education, training and employment for students with disabilities and special educational needs in the EU, An independent report prepared for the European Commission by the NESSE network of experts. . As of 16 December 2017: http://www.nesse.fr/nesse/activities/reports/activities/reports/disabilityspecialneeds-1.

Nicaise, I. (2008). Ongelijkheid en sociale uitsluiting in het onderwijs: een onuitroeibare kwaal? , 21-53.

Pameijer, N. (2006). Towards needs-based assessment: Bridging the gap between assessment and practice. Educational and Child Psychology, 23(3), 12.

Pameijer, N. (2016). Assessment for Intervention: a practice-based model. ISPA Conference.

Pameijer, N., \& Pijl, S. J. (2006). Assessment practice in the Netherlands. Assessment Project of the European Agency for Special Needs and Inclusive Education, www.europeanagency.org. 
Perera-Diltz, D. M., \& Mason, K. L. (2012). A National Survey of School Counselor Supervision Practices: Administrative, Clinical, Peer, and Technology Mediated Supervision. Journal of School Counseling, 10(4), n4.

Salas, L. (2004). Individualized educational plan (IEP) meetings and Mexican American parents: Let's talk about it. Journal of Latinos and Education, 3(3), 181-192. doi: http://dx.doi.org/10.1207/s1532771xjle0303 4

Siddiqua, A., \& Janus, M. (2017). Experiences of parents of children with special needs at school entry: a mixed method approach. Child: care, health and development. doi: doi:10.1111/cch.12443

Struyf, E., Verschueren, K., Verachtert, P., \& Adriaensens, S. (2012). Zorgbeleid in het gewoon basisonderwijs en secundair onderwijs in Vlaanderen : kenmerken, predictoren en samenhang met taakopvatting en handelingsbekwaamheid van leerkrachten Eindrapport OBPWO 09.05.

Struyf, E., Verschueren, K., Vervoort, E., \& Nijs, S. (2015). Leerlingenbegeleiding in een internationaal perspectief: een reviewstudie. [Research Report].

Tétreault, S., Freeman, A., Carrière, M., Beauprè, P., Gascon, H., \& Marier Deschênes, P. (2014). Understanding the parents of children with special needs: collaboration between health, social and education networks. Child: care, health and development, 40(6), 825-832. doi: doi:10.1111/cch.12105

Trent, S. C., Artiles, A. J., \& Englert, C. S. (1998). Chapter 8: From Deficit Thinking to Social Constructivism: A Review of Theory, Research, and Practice in Special Education. Review of research in education, 23(1), 277-307. doi: http://dx.doi.org/10.3102/0091732X023001277

Tucker, C. (2009). Low-Income African-American Caregivers' Experiences of Being Referred to Mental Health Services by the School Counselor: Implications for Best Practices. Professional School Counseling, 12(3), 240-252. doi: http://dx.doi.org/10.5330/PSC.n.2010-12.240

Van Hove, G., De Schauwer, E., Mortier, K., Bosteels, S., Desnerck, G., \& Van Loon, J. (2009). Working with mothers and fathers of children with disabilities: Metaphors used by parents in a continuing dialogue. European Early Childhood Education Research Journal, 17(2), 187-201. doi: 10.1080/13502930902951379

Verschueren, K., \& Jonniaux, S. (2015). Centra voor Leerlingenbegeleiding: op de brug tussen onderwijs en welzijn.

Williams, B., Williams, J., \& Ullman, A. (2002). Parental Involvement in Education. BMRB Social Research.

Yin, R. K. (2010). Qualitative research from start to finish: Guilford Press. 